SF 347

B8

Sopy 1

IFCTURE

DEIIVESTED IN

Campbell-Street Church, Louisville, Ky.,

APRIL 30th, 1882.

GEN'L A. BUFORD, 




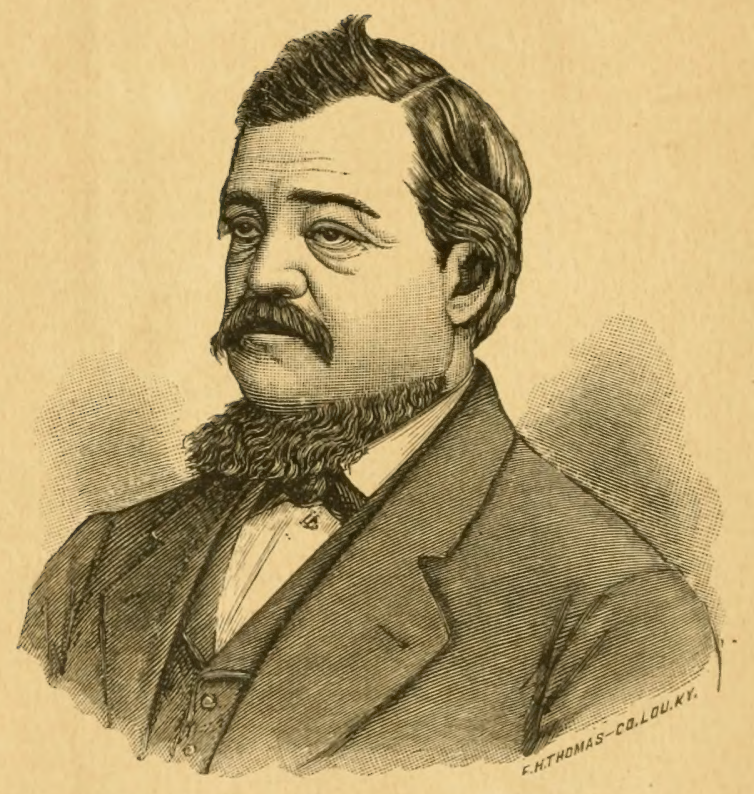




\section{CHURCH AND TURF.}

\section{エFCTUR耳}

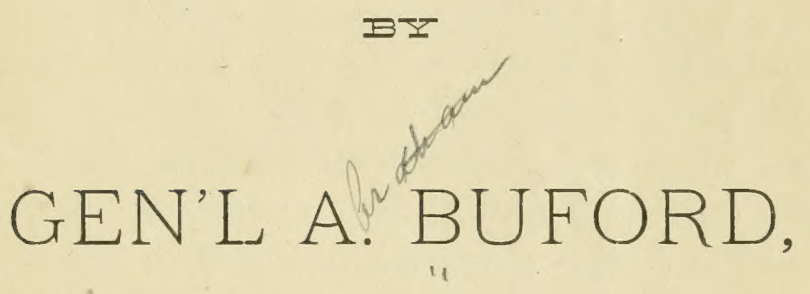

DEエIV』E巴D INT

Campbell-Street Church, Louisville, Ky.,

APRIL 30th, 1882. 


$$
\sec \frac{3 x^{7}}{3^{8}}
$$




\section{LECTURE.}

Brethren and Sisters:

It is with a feeling of the most profound respect and reverence to Him who reigns on high, and who alone has the imperial power to approve or condemn our conduct here on earth, that I have consented, in compliance with a request from our worthy pastor, to say something to you this evening. It seems presumptuous on my partfrom the fact that my early life has been led a little away from God-that I should attempt to say anything in so holy a place as this little church, and to an audience who has spent the greater part of their lives in the study of the subject of religion - a subject which I will be candid enough to acknowledge I have not given that attention to in my early life that it ought to command from all men.

Being almost an entire stranger within your gates, I have come to your little church and throw myself in your midst, seeking your advice and support in an effort to save my soul from being lost.

\section{EARLY RELIGIOUS IMPRESSIONS.}

You surely are not expecting advice and wisdom from one who has so recently buckled on his armor as a soldier of the cross. Being, as I say, something of a stranger within your gates, it will, perhaps, be more appropriate and interesting to you that what I shall say be upon the subject of my religious associations and teachings in early life, or, in other words, a little of my experience in matters touching religion, and something about horses, which will explain my course through life up to now. I 
was born in Woodford county, Kentucky, on the farm now known as Woodburn. I won't say when (but not a very great while ago, however). My parents were good and grand people. My mother-oh, what a dear mother she was! How devoted, and how hard she labored for the good of her twelve children! She was a Presbyterian, and reared her family in the faith of that church. I was christened in that church when a child. My father was a farmer and breeder of fine horses. He reared and ran many fine race-horses, so I naturally inherited my fondness for the race-horse. When a school-boy I left Kentucky and went to West Point, N. Y., where I was educated.

During the four years I was at West Point I attended the Episcopal church, and was impressed by the grandeur of its ceremonies, and formed quite a strong partiality for that church. When I graduated at West Point, I was assigned to duty in the First Regiment of Dragoons, United States Army, and for fourteen years subsequent, I served on the Western frontier in protecting the pioneer of the West from the depredations of the Indians. The first time during my service in the West I ever saw the Lord's Supper spread was at Fort Atkinson, Iowa, with the Rev. W. Lowry officiating, and with but two other communicants with him. This scene was witnessed by many of the warriors of the Winnebago tribe of Indians, some of whom asked, after the ceremony was over, if that was all right and proper, why was it that so few of the whites joined in it? To which question no satisfactory reply could be given to the Indians.

My first Captain in the dragoon service was Nathan Boone, who was a son of Daniel Boone. Capt. Nathan Boone was a good, Christian man. I have often seen him kneel in his tent on his buffalo robe and pray fer- 
vently, at which I, a young dashing dragoon, would laugh in derision at what I thought was the weakness of the old man. I now rejoice in the fact that I have lived to see the day when I am convinced that the weakness was on my part and not that of the Christian pioneer.

\section{AFTER MY MARRIAGE}

I resigned from the army and settled in Woodford county, Ky., with my dear wife and boy. Oh! what a dear wife and boy they were to me, and oh, how I miss them now! They were both members of the Episcopal church, so that you must be satisfied that I am, indeed, very partial to that church. Although my dear wife and boy were members of that church for many yeers, on account of the fact that I owned, reared and trained many fine horses, I did not join them in this the most important step in life. Oh, that I had; they might have been spared to me! Still, I have never thought it inconsistent with the life of a true Christian to own fine race-horses; yet the world, through what I conceive to be the weakness of human nature, thinks otherwise. Therefore, not wishing to bring disrepute upon the church in the opinion of the world, I did not join the church until I had parted company with the race-horses. And what attracted me to the Christian church was the simplicity of its'teachings and ceremonies, in all of which I was soon educated. By the eloquence of and through the earnest and gentle manner of our worthy pastor, I was enabled to master courage sufficient to acknowledge before man our Master in heaven.

This question touching the relative position of the

$$
\text { CHURCH AND TURF }
$$

is one, in my opinion, that strikes deeper at the interest of the church than many of our Christian friends think. It 
is a question on which I have my own views, and just here I would assure you that it is not my purpose to thrust my views on any one, and, especially, on such an audience as I find before me to-night. If we differ, let it be done in a gentle manner and in a Christian spirit, and should there be any material difference between us, let he who is in error have the candor to confess. From my occupation in life this is a question in which I have been deeply interested. I will ask you, therefore, to be a little patient while I give utterance to a few casual thoughts on the subject. Remember that the Bible teaches us to defend, protect and promote the interest of the Government under which we live. We will then ask: What interest has the Government in the development of the horse, as well as his improvement? In answer I will say

- the defense of the country and its inhabitants against all enemies, both foreign and domestic, requires the most searching improvement and development of the horse. The cavalry arm of the service, which is admitted by most all great military men of the day to be the most efficient in war, as well as the artillery arm (in the field branch of that service), need the services of the horse in his most perfect form, and with all the ability he can be found to possess in the way of strength and courage.

WE MUST HAVE A RACE-TRACK.

To reach these points in a horse he must be developed and improved by handling and breeding. How, then, are we to develop him? We must have a race-track on which to develop his capacity as to strength and durability, his speed and bottom; and, when through the racecourse we discover the horse that possesses these qualities in the greatest perfection, we will then choose him as the horse through which we will propagate and improve his species. Suppose we had been without a race-course 
since Noah left his ark with his inferior Barb or Arabian horses, our great Generals, Forrest, Stuart and Morgan, would have cut a pretty figure during the late war with their men mounted on such horses as those were.

Our artillery would be totally inefficient in the field branch of that service. What sort of a race would I have made during the war when chasing Sturgis back into Memphis mounted on one of Noah's mustang ponies? Or what would have become of me when Wilson was chasing me across the bridge near Columbus, Ga., on which the Yankee picket seized the bridle of my horse and struck me over the head with his sabre, mounted on one of Noah's horses? I would, indeed, have been a lost child. But being mounted on an improved thoroughbred, after discharging my pistol at his head, I made a rapid and successful retreat.

The most essential fact of all: The Treasury of the State would be deprived of many millions of dollars in consequence of the clepreciated value of the horse. Then again, are not the members of all churches delighted when they can get a seat behind a pair of thoroughbred horses and drive over the splendid roads and beautiful parks of the country? And may I not ask how many members of the various churches in the land are there who are not interested in the development and handling of the horse, through which they secure the means that enables them to support their respective churches? We then are, both Church and State, deeply interested in the development of the horse.

\section{THE GREAT TROUBLE.}

Now comes the great trouble, which is the management of the race-course, through which the many evils of which we know creep in and furnish the many arguments against Christian people attending the races even on Derby Day. 
Then the question is simply this: Can not these evils be corrected? We can not correct them by staying away and abandoning the whole thing to the devil and his satellites-abandon the great national sport to the hands of bad and desperate men. This is an institution in which the State of Kentucky is interested to the amount of many millions of dollars. As I said, the Bible tells us we must support the Government under which we live, and you tell me it is the duty of Christians to abandon the great interest Kentucky has in the improvement of the horse into the hands of bad men of the country by building a Chinese wall around it. I say emphatically, no! It is, in my opinion, the duty of all Christians to aid in the passage of such State laws as will correct the many evils in the management, which I will not here attempt to enumerate. Some of these evils are trifling and might, in some, degree be corrected by the presence of good, Christian people. Remember, however, that, when you should present yourself there, your purpose must be honest - to correct, and not engage in, the vices spoken of. It is with much pleasure and pride that I can truthfully state that evils alluded to in the management of the many race-courses in the United States, do not exist in Kentucky to that extent. They do in the East. In fact, the evils existing in the management of our racecourse near the city are but few, and might easily be eradicated by the earnest work of a few good, Christian men. Remember that the Louisville Jockey Club was the first to give the handsome sum of $\$ I, 800$ to the yellow fever sufferers. Christ came on earth to save sinners. How could he save them without being placed in contact with them? By this contact the turf might be made more respectable, so that all would be able to enjoy the outdoor sports of this beautiful Eden, placed here by our 
Great Master especially for our pleasure and gratification.

WHAT WE MAY MAKE DERBY DAY.

Let me read from Zachariah, chapter ix., verse 17 : "For how great is his goodness and how great His beauty. Corn shall make the young men cheerful, and new wine the maids." It is eviclent from this verse that our Heavenly Father expected us to be more cheerful on some days than others. Then, after spending a long, dreary winter in a crowded city - when the beautiful month of May rolls around, and all nature decked with flowers, and the air is balmy sweet, and the many beautiful birds are singing their love songs-may we not make Derby Day an occasion when the juice of the corn and new wines shall make the young men and maids more cheerful and happy? Christ at the wedding converted the water into wine, and all were cheerful under its influence. Are we to give up the pleasure of witnessing the Derby run when contested by twenty of the most beautiful thoroughbreds, with riders all clecked in various colors, and spending a few hours on the beautiful Jockey Club grounds, simply on account of the tact of the existence of a few evils in the management of the course?

In England, the Bishop of Canterbury always attends and witnesses the running of the English Derby, with his entire suite. This he does, doubtless, with an honesty of purpose to enjoy in a Christian spirit the national sport of the country, and by his presence to check, in a measure, some of the attending evils. Can't we follow his example with an honesty of purpose, or shall we acknowledge our weakness by admitting the danger of our falling by the wayside?

One of the great weaknesses of the Amcrican people is to imitate the English, who were the first to introduce 
the "English bob," on the tails of their race-horses. IVe followed, and bobbing is becoming so fashionable now, that the ladies of America bob the hair on their heads in imitation of this English race-horse fashion; so, if the laciles can afford to follow this fashion of bobbing the horses' tails, we certainly can afford to follow the example of the Bishop in attending the races.

Christ when He came on earth, did not fight and quarrel with the sinners, but Ile won them by His kindness and gentle reasoning. So we must do, as it is only through Christianity that we can reach the end so much to be desired in this matter.

\section{TOO STRICT CHURCHES.}

Again, the Bible says " that he that eateth and drinketh unworthily eateth and drinketh damnation to himself." So if any of us at the Lord's table should eat and drink unworthily, are the remainder of us to be driven from the holy supper table and church in consequence thereof? I say, certainly not. There have been, as we all know, many bad men in many of our churches. Are we to abandon the churches on account of the conduct of these men? On the turf are we to abandon it on account of the presence of bad men? He who on the turf is guilty of fraud, like he who "eateth and drinketh unworthily," brings damnation upon himself. Do not interpret a single sentence I have uttered to-night to mean that I would encourage your attendance on the race-course. So long as the rules governing your church forbid it, I am only advocating, with all due respect to the authorities of this dear little church a slight modification of its rules on this question. At the same time, I will be candid enough to say that in my opinion some churches, by their rigid rules of government on this and other similar questions, drive many people away from their doors. As an instance, 
I will give you the case of my particular friend, John $\mathrm{M}$. Clay, of Lexington, $\mathrm{Ky}$., who had been a turfman all his life. Some five or six years since, he concluded that the time had arrived when it was his duty to become a member of the church; so he approached the pastor of the church of his choice and made known to him his determination. The reply he got from the pastor was that he must give up his race-horses. He would then talk to him on the subject. Mr. Clay then asked him if his neighbor, who handled a large stable of trotting horses, had not recently become a member of his church. His answer was yes, but his horses are trotting horses; yours, Mr. Clay, are race-horses; we have no objection to trotting horses in our church. Then, says Mr. Clay, I understand you to be of the opinion that your members can trot but can not run into heaven. So Mr. Clay retired and joined the Catholic church.

Do not conclude from any thing I have said to-night that it is my purpose to attend the approaching races. For so long as I am a member of this church I shall do all in my power to respect and obey its rules of government. Brothers and sisters, allow me to thank you for your very kind and patient attention, and ask that our Heavenly Father shall continue you in health and prosperity and make you cheerful and happy.

I find it necessary that I should say a few words more on the question of Church and Turf, which was the subject of my talk to the members of the Campbell-street church a few evenings since. I little thought that what I had to say on this question would attract the attention it has. I certainly did not think it would arouse any 
harsh feelings or severe criticisms on the part of any editor of a Christian paper. Now that the question has attracted so much attention in many parts of the country, I wish simply to give my solution of it and I am done. I stand still precisely where my lecture places me, and have not one single $\mathrm{i}$ to dot or $\mathrm{t}$ to cross in it. My solution of the question is this: Let it rest as a question of conscience with each individual member of the church, and should a member abuse this right of conscience in the exercise of the privilege as a Christian, it would then be time enough for the church as a body to interfere.

Like the little boy who picked up the gun, "I did not know it was loaded." No one is or can be more surprised than I at the result of my late talk on the Turf and the Church. I have no other desire than the truth in this matter. The "most unkindest cut of all" is that of the Apostolic Times, which denounces the lecture, made not at my own suggestion or solicitation, in a severe, wholesale way. The "no creed" and ready investigation spirit of the church of Christ challenged my admiration and won my allegiance. I gave my honest convictions in a manly way, yet modestly, for I full wcll realize that I am a "babe in Christ." It is farthest from my desires to bring reflections upon the church, and most deeply would I lament influencing any one by word or cleed in the wrong direction. I ask that the editor of the Apostolic Times give us the teachings of the "Book" upon this subject, instead of a broadside denunciation, as no one will sit more willingly at his feet or listen more eagerly to his words than I. My earthly career is drawing more rapiclly to a close, and my great aim now is to win the race for eternal life; and, as you have before said, if I can pass through the pearly gates of heaven in a chariot drawn by Enquirer and NICWhirter, I would shout with 
great joy, and would be far in advance of you, Mr. Editor, should your chariot be drawn by a pair of Noah's mustang ponies.

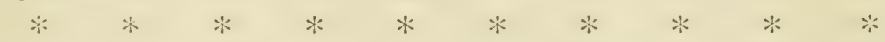

Two Sabbaths since I delivered, from the stand I now occupy, a short lecture on the subject of the "Church and Turf." The thought of my becoming a lecturer on any subject is something very novel, to me, at least, and something I had never contemplated. But still, if I find I can advance the cause of Christ and correct, in the slightest degree, the morals of this advanced age, it will give me infinite pleasure. This lecture has been copied in many papers throughout the whole country, and many have been the criticisms thereon; some of them have been a little bitter, charging that my house was not in order, and that I was not the proper person to deliver such a lecture, and regretting its delivery in the church. Others of the criticisms were more favorable, and commended the subject to the study of all good men. It is claimed that one of the good effects of the lecture has been that the Chicago Driving and Running Park have abolished the "wheel of fortune" - which is one of the vilest species of gambling ever introduced in any country-forever from their grounds. This, certainly, is one step taken in the right direction by the officers of that Park, and if brought about by the teachings of my lecture, we will give the credit all to our Master in Heaven. It is these adverse criticisms that have created a desire on my part to seek further light on the subject by asking the simple question, Whose house is in order?

The Holy Bible will answer this question; so let's turn to our text for this evening.

II Samuel, Chap. 23; Verse 5.

" Altho' my house be not so with God, yet he has "made with me an everlasting covenant." 
Such, brethren and sisters, is the language of David, the King of Israel, who was a man after "God's own heart" In this passage David has done what all good Christians ought to frequently do. He compares the conditions and surroundings of his own life on earth with what is required of him by our great Master in Heaven. IVe should not only compare our conduct and actions, but also our thoughts and opinions, with what is required of us by the teachings of the Bible. In making this comparison of ourselves, one with another, it must not be made with the view of seeing in our opinions how we will compare with standards of our own, or with human expectations. But the end desired is to learn how near we reach that standard required of us by God. In these comparisons we may oftentimes find some justification of a Christian feeling of congratulation toward one another. Still that human standard occupies so inferior a position that our exalted course of conduct in this life over that of a brother is not a sufficient cause for very great rejoicing on our part. But when, by this thorough investigation of our true condition in life, we discover its weakness and its vulnerable points, it is then that we, in imitation of the good and pious King of Isracl, would become most humbled in the dust, and exclaim as he did: "My house, my heart, my life, my con"duct, is not so with God."

These comparisons are truly humiliating, but essential to the success of our spiritual life-as God gives grace to the poor and humble, and rejects the proud and haughty - we must bear the fact well in mind, that there. is but one good and perfect life, and that is the life of Jesus; none of our lives are without stain or blemish. When, in the comparison of our lives with that of Jesus, we discover the slightest stain, we are aroused with a 
feeling of great fear and alarm for our safety, and every honest heart is humbled, and in sadness we note the alarming deficiency in our present lives, in comparison with what they ought to be in the eye of our Lord and Master. Let us see in what estimation some of the pious men of the Bible held their lives whilst struggling through this cold and heartless world. David himself says: "I have sinned against the Lord, oh, God, Thou "knowest my foolishness, and my $\sin$ is not hid from "Thee." Job speaks and says: "Oh, God, I am vile," and St. Paul gives utterance to the following wail; "Oh! " wretched man that I am, who shall deliver me from the "body of this death?" Such, my brethren, is the evidence we get from the Bible, given by some of the most pious men of modern times, and such are, doubtless, the convictions of many of us in our hearts to-day. The fact is, by an honest examination of our own hearts, it will be too plainly revealed to us, that our house is not in order, and is not so with God as we would wish it to be here.

If in this intercourse of one with another, and in making the comparisons as to the relative positions we occupy as to our opinions touching the question of religion in any way, we discover any difference we should as Christians treat that difference with great forhearances remembering that Bro. Campbell himself and a number of his members had a difference of opinion on various questions touching the government of the church. And they were treated with great forbearance, although some of them never did change their opinions. Such should be our course toward a member, whose house we consider out of order, a simple "dcnunciation" and assertion that his views " are erroneous," are not sufficient to convince the warmest hearted Christian of his errors. But 
we must point out to him wherein his reasoning is wrong, and by strong arguments prove to him that his house is not in order, as required by our Master in Heaven. Then, in this comparison don't let us confound our opinions with our faith. In all churches, members differ in a greater or less degree in their respective opinions touching the government of their churches, which differences of opinions are not essential to the salvation of their soul. And it is our duty as Christians to do all in our power to remove them, in a kind and gentle manner, without denunciation.

If we have faith in Christ, there should be but little stress laid upon opinions, "we can all be of one faith, "but never of one opinion." We must, therefore, in our efforts to assist our brethren in placing their respective houses in the condition that God requires them to be, exercise great forbearance, and in removing the mote from our neighbor's eye, we must be careful not to destroy the eye by hasty or violent action, but touch it gently as our Saviour would. Notwithstanding the existence of the fact that our house is not in order as required by our heavenly Father, still we have a covenant with God. And if we are saved at all it will be through the part we have in this covenant of grace, called the everlasting covenant. No act of our own can save us. It is only through faith in Jesus, and by virtue of that faith we make ourselves a party to this covenant, the stipulations of which are, "I will be their God and they shall be my people," whosoever believes in Jesus, repents of his sins and yields to the authority of Christ, shall be identified with the terms of this covenant. The accuser of the brethren may accuse us before God day and night; but can do no more, so long as we keep our case in the hands of the Divine Advocate. He will plead our 
cause against the insinuations of wicked men and against the wiles of his Satanic Majesty. Earth and hell can not harm us, so long as we cling to our claims for the great blessing, promised us in the covenant, and nothing can work a forfeiture of these blessings, save a wanton abandonment on our part of our religious duties and requirements towards God our Saviour. We can only sustain our relationship to this covenant through faith, through righteousness, and the blood of our crucified Christ. We can do but little ourselves, and nothing can secure us eternal salvation, save a firm reliance in our Saviour. A few words more on what is said of the horse in the Bible and I will close.

* * * * * * * * * *

Sagittarius, the archer, is represented as a Centaur. These Centaurs were represented as men from the head to the loins, while the remainder of the body was that of a horse, of which animal the ancients had so high an opinion that this union was not considered in the least degrading. In heathen mythology, one of these Centaurs, Chiron, was renowned for his skill in music, medicine, hunting and the art of prophecy. The most distinguished heroes of mythology were among his pupils. He taught Esculapius physic, Apolio music and Hercules astronomy. This illustration from the records of remote antiquity is merely introduced as an incidental illustration of man's tendency to deify or perpetuate his love for one of the noblest and most useful animals given him by Beneficent Power.

In the Scriptures so many allusions are made to the horse, that it is impossible to take more than a few of the many illustrations. From the pages of the inspired volume, we learn that God Himself in enumerating the wonders of his creative hand, as he spoke to Job out of the 
whirlwind makes mention of the noble animal in the following sublime language (Job 39th Chap., igth to $25^{\text {th }}$ verses) viz.: "Hast thou given the horse strength? hast thou clothed his neck with thunder? canst thou make him afraid as a grasshopper? The glory of his nostrils is terrible. He paweth in the valley, and rejoiceth in his strength; he goeth on to meet the armed men. He mocketh at fear and is not affrighted, neither turneth he back from the sword. The quiver rattleth against him, the glittering spear and the shicld. He swalloweth the gromind with fierceness and rage, neicher believeth he that it is the sound of the trumpet. He saith among the irumpets, IIa, ha! and he smelleth the battle afar off, the thunder of the captains, and the shouting."

In the beautiful story of Queen Esther, we have the honor which was rendered unto Mordecai in the following language :

"I:or the man whom the King delighteth to honor, Let the royal apparel be brought which the King useth to wear, and the horse that the King rideth upon, and the crown royal which is set upon his head. And let this apparel AND Horse be delivered to the hand of one of the King's most noble princes, that they may array the man with all whom the King delighteth to honor, and bring him on horscback through the street of the city," etc., etc. (Esther 6th Chap., 7th to roth verses.)

In the transiation of Elijah from earth to heaven, Gocl honored his faithful servant by sending a celestial conreyance and resplendent horses, or as the Chronicler quaintly expressed it "A chariot of fire and Horsiss of fire, (II Kings 2d Chap., i ith verse) and as the glorious equipage swept heavenward Elisha saw it and exclaimed, "My father, $M_{y}$ father, the chariot of Israel and the horsemen thereof!" Following this train of thnught we 
find that God in his infinite wisdom has incorporated the horse with the hosts of celestial beings. When the King of Syria encompassed the town of Dotham with his army in the attempt to capture Elisha, the prophet's servant awaking in the morning and seeing the town encompassed by the enemy, exclaimed, "Alas! my master how shall we do?" Elisha's reply was "Fear not, for they that be with us, are more than be with them," and then, in answer to the prophet's prayer, the eyes of the servant were opened to behold the heavenly allies, " and behold, the mountain was full of.horses and chariots of fire round about Elisha." (II King 6th Chap., I 7th verse.)

All through the Bible we find the horse spoken of as an animal brave and powerful-as an animal respected by Kings, and honored by God as instruments in the accomplishment of his heavenly designs.

From Genesis to Revelation, the horse is frequently mentioned and the direct inference given that in a celestial form, it is an inhabitant of the Courts on high. St. John in his Apocalyptic vision, Rev., I 9 th Chap., I I th to I 4 th verses, writes:

"And I saw heaven opened, and behold a rehite horse; and He that sat upon him was called 'Faithful and True,' and in righteousness He doth judge and make war. His eyes were as a flame of fire, and on his head were many crowns, and he had a name written that no man knew. but He Himself. And he was clothed in a vesture dipped in blood; and His name is called the Word of God. And the armies which were in heaven followed Him upon white horses clothed in fine linen, white and clean."

Such, my brethren, are a few passages of the Bible, in which the horse is spoken of, and in all of which he is held in great reverence by Divine writers. In none of 
these passages is the abuse of the horse alluded to. It is the abuse of this animal that makes him an enemy to some Christians of the present day, which abuse I contend can only be quieted by the prompt and decisive action of Christian people. It is my conviction that most of the members of this little church are very partial to, and fond of riding and driving, fine horses-we would not be Kentuckians were we not, and judging from the elegant style and perfect action of the horse I see our worthy pastor riding through the streets of our city daily, he must be a thoroughbred; he is a gentlemen of too much culture and taste to be satisfied with any other; you would not be, nor would I. After thanking you for patient attention, I will close by asking that our Heavenly Father will give us light, and through light, wisdom, that we may be of one opinion on all questions touching the Government of our own little church.

A. Buford. 



\section{LIBRARY OF CONGRESS}

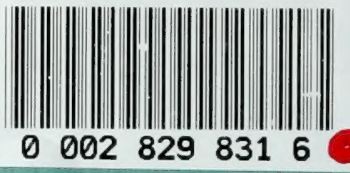

